\title{
DEVELOPMENT OF PHYSICAL AND SELF-CONTROL ABILITIES OF JUNIOR SCHOOLCHILDREN (10-11 YEARS OLD)
}

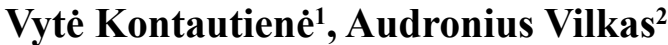 \\ Klaipèda University ${ }^{l}$, Klaipeda, Lithuania \\ Lithuanian University of Educational Sciences ${ }^{2}$ Vilnius, Lithuania
}

\begin{abstract}
Background. The goal of the research is to reveal the dynamics in physical abilities of junior school learners (1011 years old) and their links with development of self-control abilities by applying the programme for development of self-control abilities in physical education classes during the experimental period. The pedagogical experiment was carried out with 4th forms of general education schools of Klaipedda, Kaunas and Raseiniai from 2011 to 2012 and lasted for one school year. The research included 178 school learners in the experiment group $(n=85)$ and in the control group $(n=93)$.

Methods. The questionnaire method was applied to evaluate the change in self-control abilities, whereas the testing method was used to identify the change in physical abilities (flexibility, explosive power, agility, speed, balance, abdominal muscle strength and stamina).

Results. Statistically significant differences were identified among boys from the experimental and the control groups considering the results of flexibility, long jump, abdominal muscle strength and stamina $(p<.01)$, dexterity and speed $(p<.05)$ and among girls when measuring the results of flexibility, long jump, speed, balance, abdominal muscle strength and stamina $(p<.01)$. Application of Pearson's correlation, correlating links between the abilities of physical and psychosocial self-control, revealed that school learners with better abilities of psychosocial selfcontrol also demonstrated a number of better physical abilities: linear correlation links were established between psychosocial control and flexibility, explosive power, speed, stamina and balance abilities. These links showed that improvement of self-control skills had an effect on self-development of physical abilities.

Conclusion. The research has revealed a positive impact of the programme due to which development of selfcontrol abilities determined a change in physical abilities.
\end{abstract}

Keywords: self-control, physical abilities, junior schoolchildren.

\section{INTRODUCTION}

$\mathrm{P}$ hysical education in early school years increases the ability to adapt to everchanging conditions and requirements, as well as enables pupils to self-actualize, assess their physical senses and psychical condition, and develop self-control abilities. Kauffman, Davis, \& James, (2001) define self-control as an individual ability to control one's behaviour (application of strategies for problem solving) and it is related to metacognition. Metacognitive skills are self-control abilities which are formed by learning; they are thoughts about what we know, and how we control learning (Gage \& Berliner, 1994; Feuerstein, 1990; Wulf, Raupach, \& Pfeiffer, 2005; Ekflides, 2011).

Human motion is expressed by different features, skills, physical peculiarities. The education of pupils' self-control abilities to monitor their learning and its application in new situations enables them to significantly improve their problem-solving skills (Chiviacowsky, Wulf, de Medeiros, Kaefer, \& Tani, 2008; Kolovelonis $\&$ Goudas, 2012). The development of self-control 
abilities allows mastering correct movement techniques since self-control helps to understand general cognitive strategies, which leads to achieving better physical skill related results. In order to develop pupils' physical abilities, it is important to research the correlation between selfcontrol abilities and physical education among 9-10 year-old pupils as these processes interact (Baumeister \& Exline, 2000; Chiviakowsky et al., 2008; Kaefer, Chiviacowsky, Meira, \& Tani, 2014), however, in general, we may state that there is a gap in research analysing self-control abilities of elementary school learners.

Research object was the development of physical and self-control abilities of junior schoolchildren (aged 10-11) through the physical education classes.

Research aim was to reveal the junior schoolchildren's (aged 10-11) change in physical abilities and their relation with the development of self-control abilities during the experiment by applying an experimental education programme of self-control abilities during the physical education classes.

Research hypothesis. Development of selfcontrol abilities during the physical education classes positively influences physical abilities of the junior schoolchildren.

\section{Research objectives:}

1. To research and evaluate 10-11-year-old learners' change in physical abilities during one academic year experiment and to conduct a comparative analysis of the obtained results.

2. To reveal the links of self-control abilities with the development of physical abilities.

\section{METHODS}

Research methods: analysis of scientific literature, questionnaire survey, educational experiment, testing, mathematical statistics. Research data were analysed by applying the Cronbach's alpha coefficient, Pearson's correlation analysis, Student's $t$, Mann-Whitney criteria.

Research methodology. The experimental group (E) had an additional workload during the physical education classes according to our designed Developmental program of self-control abilities during the physical education classes, whereas the control group (C) proceeded following the standard physical education program, designed for the mainstream schools and was not involved in the experimental program. The pedagogical experiment was based on a theoretical model on development of self-control abilities (Figure), referring to which an assumption was made that self-control abilities as a metacognitive ability to learn and control may be transferred to a developmental area of physical abilities, and in this way creates preconditions for the development of physical abilities among the junior school learners. During the physical education classes, learners were provided with information on self-control and underwent a practical development of selfcontrol abilities. Preconditions for the development of the self-control abilities are considered as the following factors: favourable pedagogical and psychological environment, learner education by emphasizing the importance of efforts, successful learning experience, feedback, application of the behaviour learnt (generalization).

Questionnaire survey evaluates the change in self-control abilities, while testing examines the change in physical abilities (flexibility, explosive strength, agility, speed, balance, abdominal muscle strength, and stamina). The tests were chosen according to the methodology (Lietuvos gyventoju fizinio pajegumo testavimo ir fizines būkless nustatymo metodika, 2007) of testing the Lithuanian residents' physical potential and assessment of physical condition, as well as Lithuanian physical education programme "Grow and Strengthen" (Lietuvos kūno kultūros ženklo programa „Augti ir stiprèti“", 2004). Mathematical statistical data analysis pertaining to a change in physical abilities was conducted by applying a $t$ - test for independent groups and additional measurement $t$-test procedures.

The self-control questionnaire to assess physical and psychosocial control was based on the above mentioned programme "Grow and Strengthen" (Lietuvos kūno kultūros ženklo programa ,Augti ir stipréti“, 2004) and Riggio and Friedman's (1982) inventory of social skills. The assessment scale (Cronbach's Alpha .911, $n=37$ ) of self-control abilities was divided into physical and psychosocial self-control subscales.

All the measurements were conducted twice before the experiment and after it.

Research organization. The pedagogical experiment was conducted among the fourth grades of Klaipeda, Kaunas, and Raseiniai basic schools in 2011-2012. The pedagogical experiment lasted for one school year. To conduct the 


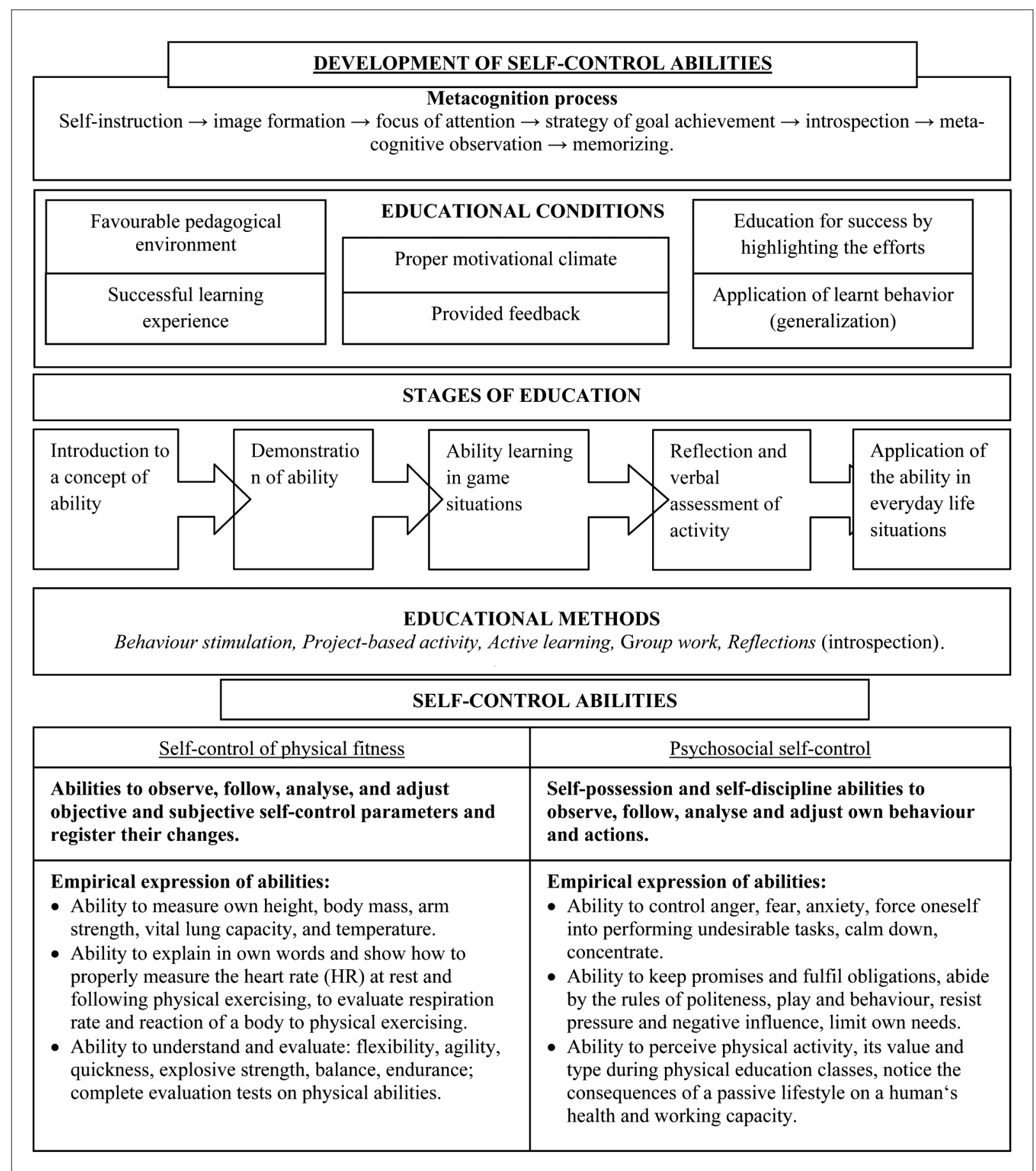

Figure 1. Theoretical model on development of self-control abilities

experiment, the schools were selected by criterion sampling considering such factors as qualification of participating teachers (senior teacher), work experience (years), number of classes, consent to participate in the experiment as well as a material base. Teachers, involved in the experimental group, were instructed in how to work with material of the experimental program. The research sample consisted of 178 pupils: experimental group (E, $n=85)$, control group (C, $n=93)$. 


\section{RESULTS}

The change in results of physical skills. After the first study, it was determined that the differences of the mean results in both the $\mathrm{E}$ and $\mathrm{C}$ groups of both genders were statistically insignificant, i.e. the groups were homogenous and met the prime provision for the reliability of the experiment. Results with recorded changes in female learners' physical abilities are presented in Table 1.

To assess the flexibility a "sit and reach" test was used. Having compared flexibility among the girls from both $\mathrm{E}$ and $\mathrm{C}$ groups, it was established that having the results only slightly different at the beginning of the experiment, flexibility abilities in both groups improved statistically significantly, however, the E group showed higher mean results.

During the experiment, the girls within the E group significantly improved the long jump results: during Study II, the average results of this test were $136.60 \pm 20.44 \mathrm{~cm}$, thus, the girls improved the results of explosive power by $12.50 \mathrm{~cm}$ on average. Such change is statistically significant $(p<.001)$. Results of the girls within the $\mathrm{C}$ group also improved; however, they were statistically insignificant. Having compared the results obtained

Table 1. Change results of girls' physical abilities

\begin{tabular}{|c|c|c|c|c|c|c|c|c|c|}
\hline \multirow{2}{*}{$\begin{array}{c}\text { Physical } \\
\text { abilities, test }\end{array}$} & \multirow{2}{*}{$\begin{array}{c}\text { Researched } \\
\text { group, } \\
\text { number } \\
n\end{array}$} & \multicolumn{2}{|c|}{ Studies } & \multirow{2}{*}{$\begin{array}{c}\text { Difference } \\
\text { of mean } \\
\text { results }\end{array}$} & \multirow{2}{*}{$\begin{array}{l}\text { Minimum } \\
\text { and } \\
\text { maximum } \\
\text { values }\end{array}$} & \multirow{2}{*}{$\begin{array}{c}\text { Test of } \\
\text { independent } \\
\text { groups } \\
p\end{array}$} & \multicolumn{3}{|c|}{$\begin{array}{c}\text { Repeated } \\
\text { measurement } t \text { test }\end{array}$} \\
\hline & & $\begin{array}{l}\text { Study I mean } \\
\text { results } \\
X \pm S x\end{array}$ & $\begin{array}{c}\text { Study II mean } \\
\text { results } \\
X \pm S x\end{array}$ & & & & $t$ & $d f$ & $p$ \\
\hline \multirow{2}{*}{$\begin{array}{c}\text { Flexibility } \\
\text { „Sit and } \\
\text { Reach“ (cm) }\end{array}$} & $\begin{array}{c}\text { E girls } \\
(n=40)\end{array}$ & $16.85 \pm 4.73$ & $21.11 \pm 5.29$ & 4.26 & $\begin{array}{l}12.12 \\
26.40 \\
\end{array}$ & $\begin{array}{c}\text { Study I } \\
.367 \\
\end{array}$ & 8.84 & 39 & $\begin{array}{l}.000 \\
* * *\end{array}$ \\
\hline & $\begin{array}{l}\text { C girls } \\
(n=48)\end{array}$ & $16.96 \pm 4.96$ & $19.88 \pm 7.15$ & 2.92 & $\begin{array}{l}12.00 \\
27.03\end{array}$ & $\begin{array}{c}\text { Study II } \\
.343\end{array}$ & 5.36 & 47 & $\begin{array}{l}.000 \\
* * *\end{array}$ \\
\hline \multirow{2}{*}{$\begin{array}{l}\text { Explosive } \\
\text { strength } \\
\text { "Long } \\
\text { Jump from } \\
\text { a Standing } \\
\text { Position" } \\
\text { (cm) }\end{array}$} & $\begin{array}{l}\text { E girls } \\
(n=40)\end{array}$ & $124.10 \pm 20.05$ & $136.60 \pm 20.45$ & 12.50 & $\begin{array}{l}104.05 \\
157.05 \\
\end{array}$ & $\begin{array}{c}\text { Study I } \\
.052 \\
\end{array}$ & 3.58 & 39 & $\begin{array}{l}.000 \\
* * *\end{array}$ \\
\hline & $\begin{array}{l}\text { C girls } \\
(n=48)\end{array}$ & $127.50 \pm 20.77$ & $132.46 \pm 23.18$ & 4.96 & $\begin{array}{l}106.73 \\
146.64\end{array}$ & $\begin{array}{l}\text { Study II } \\
\mathbf{0 0 3} * *\end{array}$ & 1.92 & 47 & .060 \\
\hline \multirow{2}{*}{$\begin{array}{c}\text { Agility } \\
\text { 10x5 shuttle } \\
\text { run (s) }\end{array}$} & $\begin{array}{c}\text { E girls } \\
(n=40)\end{array}$ & $24.64 \pm 2.02$ & $23.04 \pm 5.28$ & -1.6 & $\begin{array}{l}22.62 \\
28.32 \\
\end{array}$ & $\begin{array}{c}\text { Study I } \\
.226 \\
\end{array}$ & -2.69 & 47 & $.010 *$ \\
\hline & $\begin{array}{l}\text { C girls } \\
(n=48)\end{array}$ & $24.81 \pm 3.21$ & $23.68 \pm 1.85$ & -1.13 & $\begin{array}{c}21.6 \\
25.53\end{array}$ & $\begin{array}{c}\text { Study II } \\
.603\end{array}$ & -2.79 & 39 & $.008 * *$ \\
\hline \multirow{2}{*}{$\begin{array}{c}\text { Speed } \\
20 \mathrm{~m} \\
\text { running (s) }\end{array}$} & $\begin{array}{l}\text { E girls } \\
(n=40)\end{array}$ & $4.81 \pm 0.37$ & $4.52 \pm 0.53$ & -0.29 & $\begin{array}{l}3.99 \\
5.18 \\
\end{array}$ & $\begin{array}{c}\text { Study I } \\
.344\end{array}$ & -3.46 & 38 & $\begin{array}{l}.000 \\
* * *\end{array}$ \\
\hline & $\begin{array}{l}C \text { girls } \\
(n=48)\end{array}$ & $4.89 \pm 0.86$ & $4.73 \pm 0.60$ & -0.16 & $\begin{array}{l}4.13 \\
5.75 \\
\end{array}$ & $\begin{array}{l}\text { Study II } \\
.002 * *\end{array}$ & -4.65 & 67 & $.001 * *$ \\
\hline \multirow{2}{*}{$\begin{array}{c}\text { Balance } \\
\text { "Flamingo" } \\
\text { test (times/ } \\
\text { min) }\end{array}$} & $\begin{array}{c}\text { E girls } \\
(n=40)\end{array}$ & $7.56 \pm 0.77$ & $5.58 \pm 0.53$ & -1.98 & $\begin{array}{c}0.00 \\
22.00 \\
\end{array}$ & $\begin{array}{c}\text { Study I } \\
.115 \\
\end{array}$ & -3.75 & 47 & $\begin{array}{l}.000 \\
* * *\end{array}$ \\
\hline & $\begin{array}{l}C \text { girls } \\
(n=48)\end{array}$ & $8.28 \pm 5.21$ & $7.25 \pm 4.98$ & -1.03 & $\begin{array}{c}7.25 \\
19.00 \\
\end{array}$ & $\begin{array}{l}\text { Study II } \\
.024 * *\end{array}$ & -1.77 & 39 & .084 \\
\hline \multirow{2}{*}{$\begin{array}{l}\text { Abdominal } \\
\text { muscle } \\
\text { strength and } \\
\text { stamina } \\
\text { "sit-ups" } \\
\text { (times/30s) }\end{array}$} & $\begin{array}{c}\text { E girls } \\
(n=40)\end{array}$ & $21.20 \pm 4.81$ & $24.10 \pm 4.16$ & 2.9 & $\begin{array}{l}12.00 \\
33.00 \\
\end{array}$ & $\begin{array}{c}\text { Study I } \\
.386 \\
\end{array}$ & 4.19 & 39 & $\begin{array}{l}.000 \\
* * *\end{array}$ \\
\hline & $\begin{array}{l}\text { C girls } \\
(n=48)\end{array}$ & $21.42 \pm 4.28$ & $23.96 \pm 3.98$ & 2.54 & $\begin{array}{c}9.00 \\
31.00\end{array}$ & $\begin{array}{l}\text { Study II } \\
.041 *\end{array}$ & 4.59 & 47 & $.010 *$ \\
\hline
\end{tabular}

Note. $* * *$ - significance level $p<.001, * *$ - significance level $p<.01, *$ - significance level $p<.05$. 
during the second study in relation to the girls from groups $\mathrm{E}$ and $\mathrm{C}$, a statistically significant difference was identified by applying an independent samples $t$-test $(p=.003)$.

In order to measure agility, a shuttle run test 10 x $5 \mathrm{~m}$ was used. Results demonstrate that during the first study the girls within E group completed the agility test in $24.63 \pm 2.02 \mathrm{~s}$ on average, whereas $\mathrm{C}$ group - within $24.81 \pm 3.21 \mathrm{~s}$. At the end of the experiment, i.e. during the second study, the girls from group E improved the agility results to $23.04 \pm 5.28 \mathrm{~s}$, whereas the change among the girls within the $\mathrm{C}$ group was not that significant $(23.68 \pm 1.85 \mathrm{~s}, p>.05)$. Results within the $\mathrm{E}$ group have improved by $0.95 \mathrm{~s}$, and this difference is statistically significant $(p=.010)$. Change in agility test results among the girls from group $\mathrm{C}$ demonstrates that results within this group of girls changed statistically significantly $(p=.008)$, however, comparing the results obtained during the second study in relation to groups $\mathrm{E}$ and $\mathrm{C}$, no statistically significant differences were identified between those groups.

The $20 \mathrm{~m}$ running test was used to measure the physical abilities of speed. Even though improvement in results was observed in both of the groups, however, having compared the results obtained during the second study in relation to groups $\mathrm{E}$ and $\mathrm{C}$, a statistically significant difference was identified $(p<.01)$. The best test result within the group E was $3.99 \mathrm{~s}$, and the worst $-5.18 \mathrm{~s}$, while within the group $\mathrm{C}-$ respectively $4.14 \mathrm{~s}$ and $5.75 \mathrm{~s}$.

Balance results among the girls within the experimental group increased: during the first study, the girls in group $\mathrm{E}$ lost their balance on average $7.56 \pm 0.77$ times $/ \mathrm{min}$, while during the second study $-5.58 \pm .532$ times $/ \mathrm{min}$, and this difference was statistically significant $(p<.001)$. No statistically significant differences were identified in $\mathrm{C}$ group between the first and the second studies. Analysis of the second study results obtained from the independent samples $t$-test reveals that group E had bigger balance test changes compared to group $\mathrm{C}$, and a statistically significant change was identified between the results of those groups $(p=.024)$.

Abdominal muscle strength and stamina was measured with a "sit-ups" test. During the one academic year, results of this test in group E increased and reached $24.10 \pm 4.16$ times $/ 30 \mathrm{~s}$, $p<.001$ ), while in group $\mathrm{C}-$ up to $23.96 \pm 3.98$ times/30 s $(p=.010)$. Having compared girls' mean results obtained during the second study in respect with groups $\mathrm{E}$ and $\mathrm{C}$, it was revealed that results in group $\mathrm{E}$ of girls improved more than in group $\mathrm{C}$ and such change was statistically significant $(p=.041)$.

Changes in results of the male learners' physical abilities are presented in Table 2. Having compared the changes in flexibility results between male groups $\mathrm{E}$ and $\mathrm{C}$, it was identified that at the beginning of the experiment having the results almost the same, during the experimental program their further change was different: change in results in group E was more significant compared to group $\mathrm{C}$, however, it was not statistically significant $(p=.335)$. Flexibility results in group E improved statistically significantly $(p<.001)$.

Data obtained in the explosive leg power test reveals that long jump results in the experimental group of boys improved: mean results obtained during the first study were $141.57 \pm 18.16 \mathrm{~cm}$, while during the second study $-155.64 \pm 20.69 \mathrm{~cm}$, $(p<.001)$. Difference in results of the second study was statistically significant $(p=.005)$, as mean results of group E boys in long jumps changed more dramatically compared to group C.

Having compared the change in agility in group E boys recorded during the first and second study, statistically significant change in results was identified $(t=2.191, d f=44, p=.034)$. Difference in results within group $\mathrm{C}$ boys recorded during the first and the second study was statistically insignificant $(p>.05)$. Independent samples $t$-test results demonstrated that agility test results in group $\mathrm{E}$ boys during the second study improved more than in group $\mathrm{C}$ and a statistically significant difference was identified ( $p=.047)$.

Speed results among the boys from group E changed positively: mean results obtained during the first study were $4.68 \pm 0.08 \mathrm{~cm}$, while during the second study $-4.22 \pm 0.47 \mathrm{~s}(p=.008)$. Results obtained during the second study between groups $\mathrm{E}$ and $\mathrm{C}$ were statistically significant $(p<.01)$, as mean results concerning the speed of group $\mathrm{E}$ boys increased more significantly than that compared to group $\mathrm{C}(p<.01)$.

During the first study the boys from group E lost their balance approximately $10.18 \pm$ $5.06 \mathrm{t} . / \mathrm{min}$, while during the second study $9.34 \pm 0.81$ times $/ \mathrm{min}$, even though no statistically significant difference was identified $(p>.05)$, the same as in group C. $T$-test results in the independent groups both during the first study and the second 
Table 2. Change results of boys' physical abilities

\begin{tabular}{|c|c|c|c|c|c|c|c|c|c|}
\hline \multirow{2}{*}{$\begin{array}{c}\text { Physical } \\
\text { abilities, test }\end{array}$} & \multirow{2}{*}{$\begin{array}{c}\text { Research } \\
\text { group, } \\
\text { number } \\
n\end{array}$} & \multicolumn{2}{|c|}{ Research } & \multirow{2}{*}{$\begin{array}{l}\text { Difference } \\
\text { of mean } \\
\text { results }\end{array}$} & \multirow{2}{*}{$\begin{array}{l}\text { Minimum } \\
\text { and } \\
\text { maximum } \\
\text { values }\end{array}$} & \multirow{2}{*}{$\begin{array}{c}\text { Test of } \\
\text { independent } \\
\text { groups, } \\
p\end{array}$} & \multicolumn{3}{|c|}{$\begin{array}{c}\text { Repeated measurement } \\
t \text { test }\end{array}$} \\
\hline & & $\begin{array}{c}\text { Study I mean } \\
\text { results } \\
X \pm S x\end{array}$ & $\begin{array}{c}\text { Study II } \\
\text { mean results } \\
X \pm S x\end{array}$ & & & & $t$ & $d f$ & $p$ \\
\hline \multirow{2}{*}{$\begin{array}{l}\text { Flexibility } \\
\text { “Sit and } \\
\text { Reach” (cm) }\end{array}$} & $\begin{array}{l}\text { E boys } \\
(n=45)\end{array}$ & $13.71 \pm 6.05$ & $17.36 \pm 5.38$ & 3.65 & $\begin{array}{c}2.00 \\
25.00\end{array}$ & $\begin{array}{c}\text { Study I } \\
.321\end{array}$ & 10.09 & 44 & $.000 * * *$ \\
\hline & $\begin{array}{l}\text { C boys } \\
(n=45)\end{array}$ & $14.20 \pm 6.54$ & $15.04 \pm 7.03$ & 0.84 & $\begin{array}{c}8.00 \\
28.00 \\
\end{array}$ & $\begin{array}{c}\text { Study II } \\
.335 \\
\end{array}$ & 1.73 & 44 & .090 \\
\hline \multirow{2}{*}{$\begin{array}{c}\text { Explosive } \\
\text { strength "Long } \\
\text { Jump from } \\
\text { a Standing } \\
\text { Position" (cm) }\end{array}$} & $\begin{array}{l}\text { E boys } \\
(n=45)\end{array}$ & $141.58 \pm 18.16$ & $155.64 \pm 20.69$ & 14.07 & $\begin{array}{l}123.42 \\
176.33\end{array}$ & $\begin{array}{c}\text { Study I } \\
.555\end{array}$ & 4.46 & 44 & $.000 * * *$ \\
\hline & $\begin{array}{l}\text { C boys } \\
(n=45)\end{array}$ & $138.27 \pm 21.98$ & $143.27 \pm 24.38$ & 5.00 & $\begin{array}{l}102.00 \\
183.00\end{array}$ & $\begin{array}{l}\text { Study II } \\
.005 * *\end{array}$ & 2.25 & 44 & .052 \\
\hline \multirow{2}{*}{$\begin{array}{c}\text { Agility } \\
10 \times 5 \text { shuttle } \\
\text { run (s) }\end{array}$} & $\begin{array}{l}\text { E boys } \\
(n=45)\end{array}$ & $24.04 \pm 2.59$ & $22.27 \pm 2.15$ & -1.77 & $\begin{array}{l}21.45 \\
24.42 \\
\end{array}$ & $\begin{array}{c}\text { Study I } \\
.409 \\
\end{array}$ & -2.19 & 44 & $.034 *$ \\
\hline & $\begin{array}{l}\text { C boys } \\
(n=45)\end{array}$ & $23.77 \pm 2.07$ & $23.09 \pm 2.15$ & -0.68 & $\begin{array}{l}18.80 \\
29.59 \\
\end{array}$ & $\begin{array}{c}\text { Study II } \\
\mathbf{. 0 4 7} *\end{array}$ & -3.34 & 44 & .752 \\
\hline \multirow{2}{*}{$\begin{array}{c}\text { Speed } \\
20 \text { m running } \\
\text { (s) }\end{array}$} & $\begin{array}{c}\text { E boys } \\
(n=45)\end{array}$ & $4.68 \pm 0.08$ & $4.22 \pm 0.47$ & -0.46 & $\begin{array}{l}4.67 \\
4.44 \\
\end{array}$ & $\begin{array}{c}\text { Study I } \\
.991 \\
\end{array}$ & -2.77 & 44 & $.008 * *$ \\
\hline & $\begin{array}{l}\text { C boys } \\
(n=45)\end{array}$ & $4.62 \pm 0.49$ & $4.46 \pm 0.51$ & -0.16 & $\begin{array}{l}4.621 \\
14.46 \\
\end{array}$ & $\begin{array}{l}\text { Study II } \\
.001 * *\end{array}$ & $-1,93$ & 44 & .060 \\
\hline \multirow{2}{*}{$\begin{array}{c}\text { Balance } \\
\text { "Flamingo" } \\
\text { test (times/min) }\end{array}$} & $\begin{array}{l}\text { E boys } \\
(n=45)\end{array}$ & $10.18 \pm 5.06$ & $9.34 \pm 0.81$ & -0.84 & $\begin{array}{c}9.33 \\
23.00 \\
\end{array}$ & $\begin{array}{c}\text { Study I } \\
.532 \\
\end{array}$ & $-1,08$ & 44 & .288 \\
\hline & $\begin{array}{l}\text { C boys } \\
(n=45)\end{array}$ & $11.31 \pm 5.30$ & $10.85 \pm 6.37$ & -0.46 & $\begin{array}{l}10.84 \\
24.00 \\
\end{array}$ & $\begin{array}{c}\text { Study II } \\
.145\end{array}$ & -0.77 & 44 & .444 \\
\hline \multirow{2}{*}{$\begin{array}{l}\text { Abdominal } \\
\text { muscle } \\
\text { strength and } \\
\text { stamina } \\
\text { "Sit-ups" } \\
\text { (times/30 s) }\end{array}$} & $\begin{array}{l}\text { E boys } \\
(n=45)\end{array}$ & $22.09 \pm 0.08$ & $27.58 \pm 4.71$ & 5.49 & $\begin{array}{l}22.00 \\
34.00 \\
\end{array}$ & $\begin{array}{c}\text { Study I } \\
.629 \\
\end{array}$ & 3.89 & 44 & $.000 * * *$ \\
\hline & $\begin{array}{l}\text { C boys } \\
(n=45)\end{array}$ & $22.76 \pm 3.76$ & $24.07 \pm 3.83$ & 1.31 & $\begin{array}{l}19.00 \\
27.91\end{array}$ & $\begin{array}{c}\text { Study II } \\
. \mathbf{0 3 0} *\end{array}$ & -2.77 & 44 & $.008 * *$ \\
\hline
\end{tabular}

Note. $* * *$ - significance level $p<.001, * *$ - significance level $p<.01, *$ - significance level $p<.05$.

study were statistically insignificant. Balance test among the boys proved that female learners' balance was better compared to that of boys.

Mean results of the first study of the abdominal muscle strength and stamina test within the group E boys were $22.09 \pm 0.08$ times $/ 30 \mathrm{~s}$, while during the second study the results were more positive: $27.57 \pm 4.70$ times $/ 30 \mathrm{~s}(t=-3.89, d f=44$, $p=.000)$. Results of this test among group $\mathrm{C}$ boys also improved, however, not so significantly as in group $\mathrm{E}(p>.05)$. Individual differences are rather substantial: the highest number of sit-ups within the $\mathrm{C}$ group reached 27.91 times/30 s, the lowest 19.00 times $/ 30 \mathrm{~s}$. According to the t-test results of the independent groups, the first study results of the boys' sit-up test between groups $\mathrm{E}$ and $\mathrm{C}$ were not statistically different $(p=.629)$, while in the second study they were statistically significant $(p=.030)$.

The research revealed a positive influence of the educational programme for self-control abilities on the change of physical abilities: statistically significant $(p<.05)$ differences in physical abilities between the experimental and control groups were identified. Results among the boys from groups $\mathrm{E}$ and $\mathrm{C}$ in relation to speed, long jump $(p<.01)$, agility, abdominal muscle strength, and stamina $(p<.05)$ as well as among girls in long jump, speed, balance $(p<.01)$, abdominal muscle strength, and stamina $(p<.05)$.

Our research aimed at identifying the correlation between the development of selfcontrol abilities and physical abilities. After the 
comparative analysis of the change in physical abilities, correlations between learners' physical abilities and psychosocial self-control abilities were examined by applying Pearson's correlation (Table 3). Data of psychosocial self-control abilities were transformed into quantitative variables.

Table 3. Correlations between pupils' physical and psychosocial self-control abilities

\begin{tabular}{|c|c|c|}
\hline \multirow{2}{*}{ Physical abilities } & \multicolumn{2}{|c|}{ Psychosocial self-control } \\
\cline { 2 - 3 } & $\begin{array}{c}\text { Pearson's } \\
\text { correlation } \\
\text { coefficient } \boldsymbol{r}\end{array}$ & $\begin{array}{c}\text { Statistical value } \\
\boldsymbol{p}\end{array}$ \\
\hline $\begin{array}{c}\text { Flexibility "Sit and } \\
\text { Reach" * }\end{array}$ & -.187 & $\boldsymbol{p}=\mathbf{. 0 1 2}$ \\
\hline $\begin{array}{c}\text { Explosive strength } \\
\text { "Long Jump" ** }\end{array}$ & .211 & $\boldsymbol{p}=\mathbf{. 0 0 5}$ \\
\hline $\begin{array}{c}\text { Agility 10 x 5 shuttle run } \\
\text { Speed "20 m" ** }\end{array}$ & .005 & $p=.942$ \\
\hline $\begin{array}{c}\text { Stamina "Skipping with } \\
\text { the rope"** }\end{array}$ & .227 & $\boldsymbol{p}=.004$ \\
\hline $\begin{array}{c}\text { Balance "Flamingo"** } \\
\text { Abdominal muscle } \\
\text { strength and stamina } \\
\text { (torso strength) "Sit-ups" }\end{array}$ & .219 & $\boldsymbol{p}=. \mathbf{0 0 3}$ \\
\hline
\end{tabular}

Note. ${ }^{*} *$ - significance level $p<.01,{ }^{*}$ - significance level $p<.05$.

Having applied the Pearson's correlation coefficient, correlations between pupils' physical and psychosocial self-control abilities revealed that pupils with better psychosocial self-control abilities had better developed some of the physical abilities: direct correlations between psychosocial selfcontrol and flexibility, explosive strength, speed, stamina, and balance abilities were identified. These correlations show that improvement in self-control abilities influences development of physical abilities: development of self-control as a metacognitive ability allowed better mastering of correct movement techniques, and thus created the preconditions to achieve better physical abilities.

The analysis of psychosocial self-control scale variables leads to the assumption that pupils who are able to control and suppress soreness $(p<.01)$ and to adapt easily to different requirements ( $p<$ $.05)$ had better balance abilities, were able to feel and assess tiredness and their pulse rate showed better stamina abilities. These findings are essential for the development of pupils' physical abilities during the physical education classes.

\section{DISCUSSION}

Our conducted research has revealed that selfcontrol abilities can be successfully developed at a younger school age (10-11) through the physical education classes. According to some authors, social skills necessary to overcome everyday life difficulties and critical situations can be started to improve even at an earlier age (Monkevičienè, Mishara, \& Dufour, 2006). Cecchini, Montero, Alonso, Izquierdo, and Contreras (2007), having investigated the influence of personal and social responsibility of school age learners on self-control and playing by the rules by using Hellison's model (1995, as cited in Cecchini et al., 2007), confirmed that a junior school age is the optimum age for the development of self-control abilities through the physical education and sport-related training. Data obtained during our research established that development of self-control abilities during physical education classes positively influenced physical abilities of children at a junior school age.

Statements on significance of self-control pertaining to the ability to learn confirm the use of metacognitive strategies in teaching (learning) movement. This is consistent with the studies, conducted by different authors (Zimmerman \& Kitsantas, 1996, 2005). According to the data obtained by Kolovelonis and Goudas (2012), students who received more accurate feedback outperformed in the chest pass test than those who received less accurate feedback.

Self-controlled practice enhances motor learning (Kaefer et al., 2014). Studies conducted by Chivacowsky et al. (2008) with 10-year-old children validate the benefit of self-control ability for learning the movement techniques. Wulf et al. (2005) argue that learning through observation, or modelling, is a commonly used technique in teaching motor skills. A recent study examined whether giving the learner control over the model presentation schedule could enhance learning, if observational and physical practices are combined. In fact, several studies demonstrated that selfcontrolled practice could benefit the effectiveness of motor skill learning. Results obtained during the present research are consistent with such insights.

Our research shows that self-control abilities are important for everyone in order to develop 
physical abilities, therefore, self-control should be taught in primary schools by explaining its meaning and importance in order to facilitate the proper organization and implementation of physical education process. It is purposeful to conduct further research which could reveal whether pupils are able to apply developed self-control skills in a long-term run, because if skills are not continuously developed, they become weaker (Bandura, 1997).

Similar self-control research was conducted by Riggio and Friedman (1982), Malinauskas, Klizas, and Šniras (2008), but they researched self-control in a wider context of the basic social skills. As basic social skills are automatic abilities, it is obvious that pupils can develop and strengthen them. Self-control abilities enable to timely notice negative changes in the body and help avoid unfavourable consequences. Physical education enables self-control not only to follow and analyse, but also to improve health condition, physical development, and physical fitness, psychical condition, emotions and actions, recognize one's body changes. This idea is also supported by the Primary and General Education Programmes (Pradinio ir pagrindinio ugdymo bendrosios programos, 2008), which state that physical activity encourages the ability to adapt to constantly changing conditions and requirements and enables the person to know oneself, one's individuality, develop physical and mental stamina, self-control abilities, which are necessary in different critical life situations.

Research by Batutis and Kardelis (2002) confirms links between the students' physical self-development and mental health. Physical balance has improved statistically significantly $(p<.05)$ together with the students' mental selfcontrol abilities, which reveal that physical selfdevelopment positively influences mental health. Students who possess strong self-control tend to flexibly react to changing situations, manage their emotions and effectively seek good sport results (Cecchini et al., 2007).

In conclusion, it is obvious that self-control abilities of the primary school learners have been little researched. We have not revealed all the factors which influence person's control in certain situations; for example, some pupils can be unable to use self-control skills due to numerous cognitive, emotional, and environmental factors, while others simply do not possess them. Strong emotions (e.g. anger, euphoria) can prevent from using one's social skills. We suggest conducting further studies, which might shed some light upon an analysis of how long children manage to apply their self-control abilities developed if such are not constantly improved. According to some authors, neglected self-control abilities weaken (Bandura, 1997) or fade away after a major pressure, however, they recover after rest and improve with exercising (Baumeister \& Exline, 2000). Based on the data obtained during the studies conducted by Monkevičienè et al. (2006), abilities developed and attained by children are enduring, even in the cases when children neglect their improvement.

\section{CONCLUSIONS}

1. Statistically significant differences between the experimental and control groups' physical abilities revealed positive influence of the educational programme for self-control abilities on the change of physical abilities: the mean results of boys' flexibility, long jump, abdominal muscle strength, and stamina $(p<.01)$, agility and speed $(p<.05)$ statistically significantly improved. During the experiment, girls' flexibility, long jump, speed, balance, abdominal muscle strength, and stamina $(p<.01)$ results also significantly improved. Development of self-control as a metacognitive ability allowed mastering the correct movement techniques, and thus created preconditions to achieve better physical abilities related results.

2. Pupils with better psychosocial self-control abilities possess better physical abilities. Identified direct correlations show the following links between psychosocial selfcontrol and physical abilities: flexibility, explosive strength, speed, stamina, and balance. The improvement of self-control abilities influences the development of physical abilities. 


\section{REFERENCES}

Bandura, A. (1997). Self-efficacy: The exercise of control. New York: Freeman.

Batutis, 0., \& Kardelis, K. (2002). Moksleivių socialinès izoliacijos, integracijos ir savigarbos sąsaja su fiziniu aktyvumu II. Ugdymas. Kūno kultūra. Sportas, 2, 10-17.

Baumeister, R. F, \& Exline, J. J. (2000). Self-control, morality and human strength. Journal of Social and Clinical Psychology, 19, 29-42.

Cecchini, J. A., Montero, J., Alonso, A., Izquierdo, M., \& Contreras, O. (2007). Effects of personal and social responsibility on fair play in sports and self-control in school-aged youths. European Journal of Sport Science, 7(4), 203-212. Retrieved from http://web.ebscohost. com/ehost/detail?vid=6\&hid=107\&sid=34el1 782d-ba11-46d0-9e

Chiviakowsky, S., Wulf, G., de Medeiros, F. L., Kaefer, A., \& Tani, G. (2008). Learning benefits of selfcontrolled knowledge of results in 10 year old. Research Quarterly for Exercise \& Sport, 79 (3), 405-410.

Ekflides, A. (2011). Interactions of metacognition with motivation and affect in self-regulated learning: The MASRL model. Educational Psychologist, 46, 6-25.

Feuerstein, R. (1990). The theory of structural modifiability. In B. Z. Presseisen (Ed.), Learning and thinking styles: Classroom interaction. Washington, DC: National Education Associations.

Gage, N. L., \& Berliner, D. C. (1994). Pedagogine psichologija. Vilnius: Alma Litera.

Hellison, D. (1985). Goals and strategies for teaching physical education. Human Kinetics Publishers, Champaign: IL. Retrieved from http://web.a.ebscohost. com/ehost/detail/detail?vid=12\&sid=ad82836e-68be4c3a-a54d-a17557d2d0b\%40sessionmgr4005\&hid $=42$ 12\&bdata $=$ JnNpdGU9ZWhvc3QtbGl2ZQ\%3d\%3d\#db $=$ eric \&AN=ED258950

Kaefer, A., Chiviacowsky, S., Meira, C., \& Tani, G. (2014). Self-controlled practice enhances motor learning in introverts and extroverts. Research Quarterly for Exercise \& Sport, 85(2), 226-233. Retrieved from http://web.a.ebscohost.com/ehost/ detail/detail? vid=22\&sid=ad82836e-68be-4c3a-a54d9 a17557d2d0b\%40sessionmgr4005\&hid $=4212 \&$ bdata $=$ JnNpdGU9ZWhvc3QtbGl2ZQ\%3d\%3d\#db=f5h\&AN $=96356734$

Kauffman, J. M., Davis, C. P., \& James, M. (2001). Self-concept, higher-order thinking and teaching of two-meta-analyses. Elementary School Journal, 101, 355-358.

Kolovelonis, A., \& Goudas, M. (2012). Students' recording accuracy in the reciprocal and the selfcheck teaching styles in physical education. Educational Research and Evaluation, 18(8), 733-747. Retrieved from http://web.a.ebscohost.com/ehost/detail/ detail? $\mathrm{vid}=55 \& \mathrm{sid}=$ ad $82836 \mathrm{e}-68 \mathrm{be}-4 \mathrm{c} 3 \mathrm{a}-\mathrm{a} 54 \mathrm{~d}-9 \mathrm{a} 17$ $557 \mathrm{~d} 2 \mathrm{~d} 0 \mathrm{~b} \% 40$ sessionmgr4005\&hid $=4212 \&$ bdata $=\mathrm{Jn}$ NpdGU9ZWhvc3QtbG12ZQ\%3d\%3d\#db=eric\& AN $=\mathrm{EJ} 982008$

Lietuvos gyventoju fizinio pajègumo testavimo ir fizinès būklès nustatymo metodika. Mokomoji knyga. (2007). Sud. A. Muliarčikas. Vilnius: LSIC.

Lietuvos kūno kultūros ženklo programa „,Augti ir stiprèti “. (2004). Sud. S. Norkus. Šiauliai: Šiaurès Lietuva.

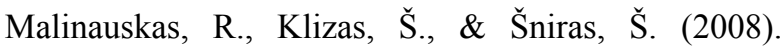
Vidurinio mokyklinio amžiaus moksleivių socialinė adaptacija kūno kultūros pamokų metu. Ugdymas. Kūno kultūra. Sportas, 2(69), 52-56.

Monkevičienè, O., Mishara, B. L., \& Dufour, S. (2006). Effects of the Zippy's Friends Programme on Children's coping abilities during the transition from kindergarten to elementary school. Early Childhood Education Journal, 34(1), 53-60.

Pradinio ir pagrindinio ugdymo bendrosios programos. (2008). Retrieved from http://www.pedagogika.lt

Riggio, R. E., \& Friedman, H. S. (1982). The interrelationships of self-monitoring factors, personality, traits, and nonverbal social skills. Journal of Nonverbal Behaviour, 7, 33-45.

Wulf, G., Raupach., M., \& Pfeiffer, F. (2005). Selfcontrolled observational practice enhances learning. Research Quarterly for Exercise and Sport, 76(1), 107-111

Zimmerman, B. J., \& Kitsantas, A. (1996). Self-regulated learning of a motor skill: The role of goal setting and monitoring. Journal of Applied Sport Psychology, 8, 69-84.

Zimmerman, B. J., \& Kitsantas, A. (2005). The hidden dimension of personal competence: Self-regulated learning and practice. In A. J. Elliot \& C. S. Dweck (Eds.), Handbook of competence and motivation, 509526. New York: Guilford Press. 